The Potential For Exploitation By Sports Franchises

by

Paul M. Sommers

July 2003

MID DLEBURY COLLEGE ECONO MICS D ISCUSSION PAPER NO. 03-18

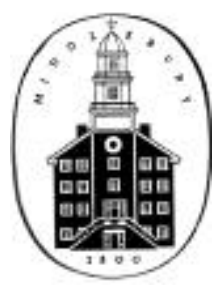

DEPARTMENT OF ECONOMICS

MIDDLEBURY COLLEGE

MIDDLEBURY, VERMO NT 05753

http:/ / www.middlebury.edu/ econ 


\section{THE POTENTIAL FOR EXPLOITATION BY SPORTS FRANCHISES}

by

Paul M. Sommers

Department of Economics

Middlebury College

Middlebury, Vermont 05753

JEL \#: D42, D60 


\section{THE POTENTIAL FOR EXPLOITATION BY SPORTS FRANCHISES}

Teams exploit their monopoly power by forcing cities to buy more games than would be dictated by the conventional monopoly model. Leeds and von Allmen [The Economics of Sports (2002), p. 164] note: "Since the city cannot choose to host a franchise for a smaller part of a season at a lower price, it must pay the full price or have no franchise at all." The city's residents nonetheless enjoy a surplus so long as the city buys all the games $\left(\mathrm{Q}_{\mathrm{m}}\right)$ dictated by the demand curve at the monopoly price $\left(\mathrm{p}_{\mathrm{m}}\right)$.

If, however, teams confront cities with an all-or-nothing choice, they can induce cities to host more than $\mathrm{Q}_{\mathrm{m}}$ games. Such action results in a loss of consumer surplus. When does this loss offset the city's initial consumer surplus? If games are produced under conditions of constant cost and the demand schedule for games is a straight line over the relevant range, the size of the loss catches up with the size of the surplus when the city is forced to host $2 \mathrm{Q}_{\mathrm{m}}$ games. Moreover, it can be shown that the loss is equal to one-half of the city's outlay $\left(\mathrm{p}_{\mathrm{m}} \cdot \mathrm{Q}_{\mathrm{m}}\right)$ divided by their elasticity of demand for games. 